\title{
Synthesis of Trevorite to Capture Tc
}

C Tsui

September 2011

Pacific Northwest

NATIONAL LABORATORY

Proudly Operated by Battelle Since 1965 


\title{
DISCLAIMER
}

This report was prepared as an account of work sponsored by an agency of the United States Government. Neither the United States Government nor any agency thereof, nor Battelle Memorial Institute, nor any of their employees, makes any warranty, express or implied, or assumes any legal liability or responsibility for the accuracy, completeness, or usefulness of any information, apparatus, product, or process disclosed, or represents that its use would not infringe privately owned rights. Reference herein to any specific commercial product, process, or service by trade name, trademark, manufacturer, or otherwise does not necessarily constitute or imply its endorsement, recommendation, or favoring by the United States Government or any agency thereof, or Battelle Memorial Institute. The views and opinions of authors expressed herein do not necessarily state or reflect those of the United States Government or any agency thereof.

\author{
PACIFIC NORTHWEST NATIONAL LABORATORY \\ operated by \\ BATTELLE \\ for the \\ UNITED STATES DEPARTMENT OF ENERGY \\ under Contract DE-AC05-76RL01830
}

Printed in the United States of America
Available to DOE and DOE contractors from the Office of Scientific and Technical Information,
P.O. Box 62, Oak Ridge, TN 37831-0062;
ph: (865) 576-8401
fax: $(865) 576-5728$
email: reports@adonis.osti.gov

\author{
Available to the public from the National Technical Information Service \\ 5301 Shawnee Rd., Alexandria, VA 22312 \\ ph: (800) 553-NTIS (6847) \\ email: orders@ntis.gov <http://www.ntis.gov/about/form.aspx> \\ Online ordering: http://www.ntis.gov
}




\section{Synthesis of Trevorite to Capture Tc}

C Tsui

September 2011

Prepared for

the U.S. Department of Energy

under Contract DE-AC05-76RL01830

Pacific Northwest National Laboratory

Richland, Washington 99352 



\begin{abstract}
Spinel containing technetium can be used to prevent Tc volatilization during vitrification of radioactive waste. Spinel dissolves in glass at elevated temperatures. This study focuses on the synthesis of spinel and the retention of rhenium, a nonradioactive surrogate for Tc in the crystals. To produce trevorite, a nickel-iron spinel $\left(\mathrm{NiFe}_{2} \mathrm{O}_{4}\right)$, Fe and Ni nitrates were mixed with alkali nitrates along with $\mathrm{Al}(\mathrm{OH})_{3}$ and heated to 500 to $800^{\circ} \mathrm{C}$. The trevorite content in samples (up to 40 mass\%) was measured with x-ray diffraction. Viable samples were rerun with $\mathrm{KReO}_{4}$. Scanning electron microscopy-energy dispersive spectroscopy detected that Re became partly immobilized in spinel-forming crystals.
\end{abstract}





\section{Acknowledgments}

The author is grateful to the U.S. Department of Energy's Hanford Tank Waste Treatment and Immobilization Plant Federal Project Office, Engineering Division, for financial support and Albert Kruger for his assistance and guidance.

I would also like to thank my mentors Pavel Hrma and Michael Schweiger for their patience and guidance on this project. I want to extend my thanks to Carmen Rodriguez for help with sample preparation, along with Brian J. Riley, Jarrod Crum, and Jose Marcial for help with analyses. Lastly, I would like to thank Elaine King, the Community College Institute program, and the Pacific Northwest National Laboratory for the internship opportunity. Pacific Northwest National Laboratory (PNNL) is operated for the U.S. Department of Energy by Battelle under Contract DE-AC05-76RL01830. 



\subsection{Introduction}

Because of their physical flexibility and chemical stability, spinels are used in various applications. Spinel crystals were also observed to contain high concentrations of rhenium [1], which makes spinel crystals suitable for immobilization of technetium (Tc), a radioactive waste product chemically similar to rhenium (Re). Neither Tc nor Re can be directly retained in High Level Waste (HLW) glass because they volatilize before the glass is formed. However, Tc or Re-containing spinel crystals have a good chance of preserving these elements until a high temperature at which the crystals dissolve in molten glass [2].

This study focused on trapping Re in trevorite $\left(\mathrm{NiFe}_{2} \mathrm{O}_{4}\right)$. Senthilkumar et. al [3] synthesized trevorite from molten salts. Unlike these authors, who produced trevorite at $900^{\circ} \mathrm{C}$, trapping Re requires temperatures as low as possible, preferably below $500^{\circ} \mathrm{C}$. Therefore, we selected $\mathrm{Ni}$ and Fe nitrates as starting chemicals mixed them with alkali nitrates in proportions close to the eutectic (Fig. 1). After the spinel was successfully produced at $500^{\circ} \mathrm{C}$, we repeated the experiment with $\mathrm{KReO}_{4}$ added to the mixture. The product is being chemically analyzed at this stage.

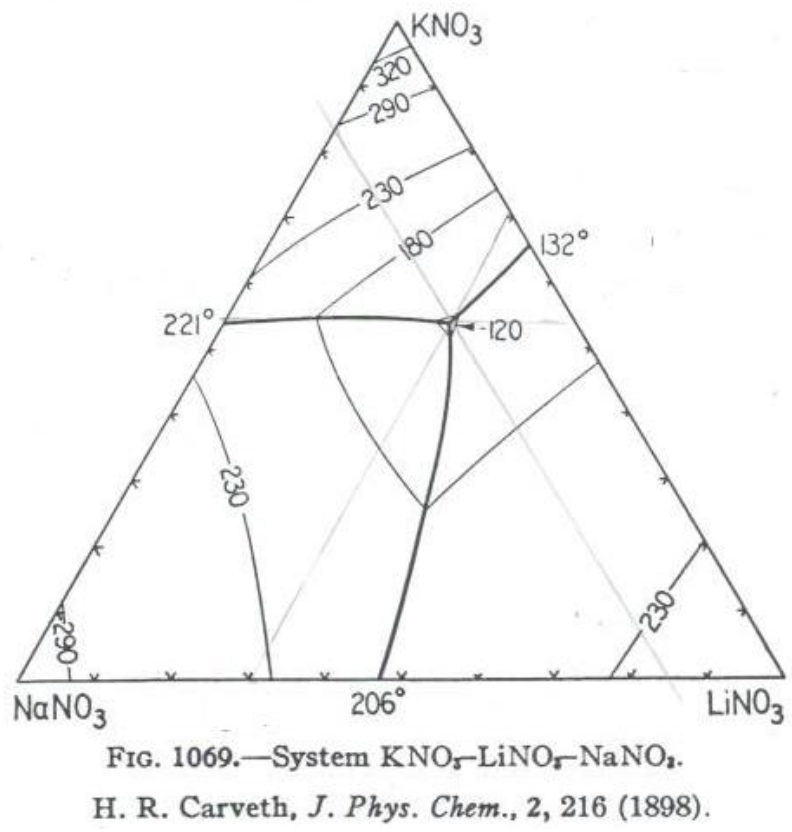

Figure 1. $\mathrm{NaNO}_{3}-\mathrm{LiNO}_{3}-\mathrm{KNO}_{3}$ Phase Diagram [4] 



\subsection{Experimental Method}

As Figure 1 shows, the $\mathrm{NaNO}_{3}-\mathrm{LiNO}_{3}-\mathrm{KNO}_{3}$ ratio to achieve a melting point of $120^{\circ} \mathrm{C}$ is approximately $0.17: 0.3: 0.53$ by mass. This mixture was prepared from analytical grade chemicals, blended with mortar and pestle and melted at $180^{\circ} \mathrm{C}$ in an oven. The melt was cooled down to room temperature. It turned to melt on reheat to $130^{\circ} \mathrm{C}$. This alkali nitrate mixture was used as an additive in the spinel batches listed in Table 1.

The nitrate mixtures shown in Table 1 contain, in varying proportion, Fe and Ni nitrates, alkali nitrate eutectic mixture, and either $\mathrm{B}_{2} \mathrm{O}_{3}$ or $\mathrm{Al}(\mathrm{OH})_{3}$, added to bond alkalis from decomposed nitrates. A batch of several known spinel-forming components, Table 2, was also tried. Table 3 shows a mixture of CT1.850 sample with chloride salts. This sample was heated to $900^{\circ} \mathrm{C}$. Note that the maximum heat-treatment temperature was appended to the sample ID.

Samples were heated from $200^{\circ} \mathrm{C}$ until maximum temperatures at $5^{\circ} \mathrm{C} / \mathrm{min}$. Heat-treated samples were then analyzed by x-ray diffraction (XRD) and scanning electron microscopy-energy dispersive spectroscopy (SEM-EDS) for structure and composition. Based on XRD data (with $5 \% \mathrm{CaF}_{2}$ as an internal standard), composition CT4A was selected for mixing with $\mathrm{KReO}_{4}$. Two samples were prepared, one with Re/Ni molar ratio 0.5 and the other 1 . For SEM-EDS analysis, the Re containing samples were washed with hot water, dried, mounted in epoxy and polished. ${ }^{1}$

Table 1. Composition of Nitrate Mixtures in Mass Fractions ${ }^{(a)}$

\begin{tabular}{c|cccccc} 
& $\mathbf{C T 1}$ & $\mathbf{C T 2}$ & $\mathbf{C T 3 A}$ & $\mathbf{C T 3 B}$ & $\mathbf{C T 4 A}$ & $\mathbf{C T 4 B}$ \\
\hline $\mathbf{L i N O}_{3}$ & 0.0338 & 0.0215 & 0.0288 & 0.0257 & 0.0288 & 0.0257 \\
$\mathbf{N a N O}_{3}$ & 0.0597 & 0.0380 & 0.0508 & 0.0454 & 0.0508 & 0.0454 \\
$\mathbf{K N O}_{3}$ & 0.1054 & 0.0671 & 0.0898 & 0.0801 & 0.0898 & 0.0801 \\
$\mathbf{N i}\left(\mathbf{N O}_{3}\right)_{2} \mathbf{6}^{*} \mathbf{H}_{2} \mathbf{O}$ & 0.3353 & 0.2136 & 0.2835 & 0.2531 & 0.1793 & 0.1600 \\
$\mathbf{F e}\left(\mathbf{N O}_{3}\right)_{3} \mathbf{*}_{\mathbf{9}} \mathbf{O}$ & 0.4658 & 0.2967 & 0.3939 & 0.3516 & 0.4982 & 0.4447 \\
$\mathbf{H}_{\mathbf{3}} \mathbf{B O} \mathbf{O}_{3}$ & 0.0000 & 0.3631 & 0.0000 & 0.0000 & 0.0000 & 0.0000 \\
$\mathbf{B}_{\mathbf{2}} \mathbf{O}_{3}$ & 0.0000 & 0 & 0.0000 & 0.2441 & 0.0000 & 0.2441 \\
$\mathbf{A l}(\mathbf{O H})_{3}$ & 0 & 0 & 0.1532 & 0 & 0.1532 & 0
\end{tabular}

(a) Sample CT1 was heated to $850^{\circ} \mathrm{C}, \mathrm{CT} 2$ to $900^{\circ} \mathrm{C}$, and the remaining samples to 600 and $800^{\circ} \mathrm{C}$.

Table 2. Composition of SS-A spinel [5] Components in Mass Fractions

\begin{tabular}{|c|c|c|}
\hline & CT5Li & CT5,2Li \\
\hline $\mathrm{LiNO}_{3}$ & 0.1281 & 0.2561 \\
\hline $\mathrm{Ni}\left(\mathrm{NO}_{3}\right)_{2} * 6 \mathrm{H}_{2} \mathrm{O}$ & 0.1401 & 0.1195 \\
\hline $\mathrm{Fe}\left(\mathrm{NO}_{3}\right)_{3} * 9 \mathrm{H}_{2} \mathrm{O}$ & 0.6509 & 0.5553 \\
\hline $\mathrm{Cr}\left(\mathrm{NO}_{3}\right)_{3} * 9 \mathrm{H}_{2} \mathrm{O}$ & 0.0656 & 0.0560 \\
\hline $\mathrm{Mn}_{3} \mathrm{O}_{4}$ & 0.0153 & 0.0130 \\
\hline
\end{tabular}

${ }^{1} \mathrm{KReO}_{4} ; \rho=4887 \mathrm{~kg} / \mathrm{m}^{3} ; \mathrm{T}_{\text {melting }}=550^{\circ} \mathrm{C}, \mathrm{T}_{\text {boiling }}=1360-1370^{\circ} \mathrm{C}$; solubility in cold water $12.1 \mathrm{~g} / \mathrm{L}$ and in hot water $140 \mathrm{~g} / \mathrm{L}$. 
Table 3. Nitrate Mixture with Chloride Salts in Mass Fractions

\begin{tabular}{l|c} 
& $\mathbf{C T 6}$ \\
\hline $\mathbf{L i N O}_{3}$ & 0.0169 \\
$\mathbf{N a N O}_{3}$ & 0.0298 \\
$\mathbf{K N O}_{3}$ & 0.0527 \\
$\left.\mathbf{N i}_{(} \mathbf{N O}_{3}\right)_{2} * \mathbf{6 H}_{2} \mathbf{O}$ & 0.1676 \\
$\mathbf{F e}\left(\mathrm{NO}_{3}\right)_{3} * \mathbf{9 H}_{2} \mathbf{O}$ & 0.2329 \\
$\mathbf{N a C l}$ & 0.2197 \\
$\mathbf{K C l}$ & 0.2803 \\
\hline
\end{tabular}




\subsection{Results}

Table 4 lists the results of XRD analysis. Spinels, trevorite and magnetite (and possibly lithium iron oxide), occurred in CT4 samples, which contained $\mathrm{B}_{2} \mathrm{O}_{3}$ or $\mathrm{Al}(\mathrm{OH})_{3}$ additions(it is possible that lithiumcontaining crystals can also carry Re into glass). Table 5 shows the XRD results of semi-quantitative analysis with JADE and TOPAS. Figure 2 shows Ni and Fe content in samples based on the stoichiometric compositions of the crystalline compounds. The data scatter is large, and no temperature effect can be discerned. The average yield is $42 \pm 17 \%$ for Ni, and $71 \pm 16 \%$ for Fe. As Table 6 shows, 48$71 \%$ of $\mathrm{KReO}_{4}$ was retained in the sample. The rest, $29-52 \%$, partly evaporated and partly became incorporated in spinel.

Table 4. XRD Results of CT1-CT6 $6^{(\mathrm{a})}$

\begin{tabular}{|c|c|c|c|c|c|c|c|c|}
\hline Sample & $\mathbf{T}$ & $\mathbf{M}$ & LF & LN & $\mathbf{F}$ & $\mathbf{N}$ & FNB & $\mathbf{K}$ \\
\hline CT1.850 & & & & $x$ & $x$ & $x$ & & $x$ \\
\hline CT2.900 & & & & & $\mathrm{x}$ & & $\mathrm{X}$ & \\
\hline СТЗА600 & & & $\mathrm{X}$ & & & $\mathrm{x}$ & & $\mathrm{x}$ \\
\hline СТЗВ600 & & & & & & & & \\
\hline CT4A600 & $\mathrm{x}$ & $\mathrm{x}$ & & & & & & $\mathrm{x}$ \\
\hline CT4A800 & & $\mathrm{x}$ & & & & & & \\
\hline СТ4B600 & & $\mathrm{x}$ & & & $\mathrm{X}$ & & & \\
\hline CT4B800 & $\mathrm{x}$ & & & & $\mathrm{x}$ & & & \\
\hline CT5Li600 & & & $\mathrm{x}$ & & & $\mathrm{x}$ & & \\
\hline CT5Li800 & & & $\mathrm{x}$ & $\mathrm{x}$ & & $\mathrm{x}$ & & \\
\hline CT5,2Li600 & & & $\mathrm{x}$ & & & $\mathrm{x}$ & & \\
\hline CT5,2Li800 & & & $\mathrm{x}$ & & & $\mathrm{x}$ & & \\
\hline CT6.900 & & & $\mathrm{x}$ & & & $\mathrm{x}$ & & \\
\hline
\end{tabular}

(a) $\mathrm{F}=\mathrm{Fe}_{2} \mathrm{O}_{3}, \mathrm{FNB}=\mathrm{FeNi}_{2} \mathrm{BO}_{5}, \mathrm{~K}=\mathrm{KNO}_{3}, \mathrm{LF}=\mathrm{LiFeO}_{2}, \mathrm{LN}=\mathrm{Li}_{0.4} \mathrm{Ni}_{1.6} \mathrm{O}_{2}, \mathrm{M}=\mathrm{Fe}_{3} \mathrm{O}_{4}, \mathrm{~N}=\mathrm{NiO}, \mathrm{T}=$ $\mathrm{NiFe}_{2} \mathrm{O}_{4}$

Table 5. XRD Results of CT4A in Mass Fractions

\begin{tabular}{c|c|c|c|c|c|c|c|c}
$\mathbf{R e} / \mathbf{N i}$ & $\mathbf{T},{ }^{\circ} \mathbf{C}$ & $\mathbf{T}$ & $\mathbf{M}$ & $\mathbf{L F}$ & $\mathbf{L P}$ & $\mathbf{L N}$ & $\mathbf{N}$ & $\mathbf{K}$ \\
\hline 0 & 500 & 0.111 & 0.166 & - & - & - & - & - \\
0 & 600 & 0.286 & 0.084 & 0.217 & - & - & - & 0.122 \\
0 & 700 & - & 0.264 & 0.111 & - & - & 0.053 & - \\
0 & 800 & - & 0.175 & - & 0.093 & 0.083 & - & - \\
1 & 600 & 0.149 & 0.034 & - & - & - & - & - \\
1 & 800 & - & 0.198 & - & - & 0.093 & - & - \\
0.5 & 600 & 0.223 & 0.017 & - & 0.048 & - & - & 0.103 \\
0.5 & 800 & 0.082 & 0.205 & - & - & - & - & - \\
\hline
\end{tabular}




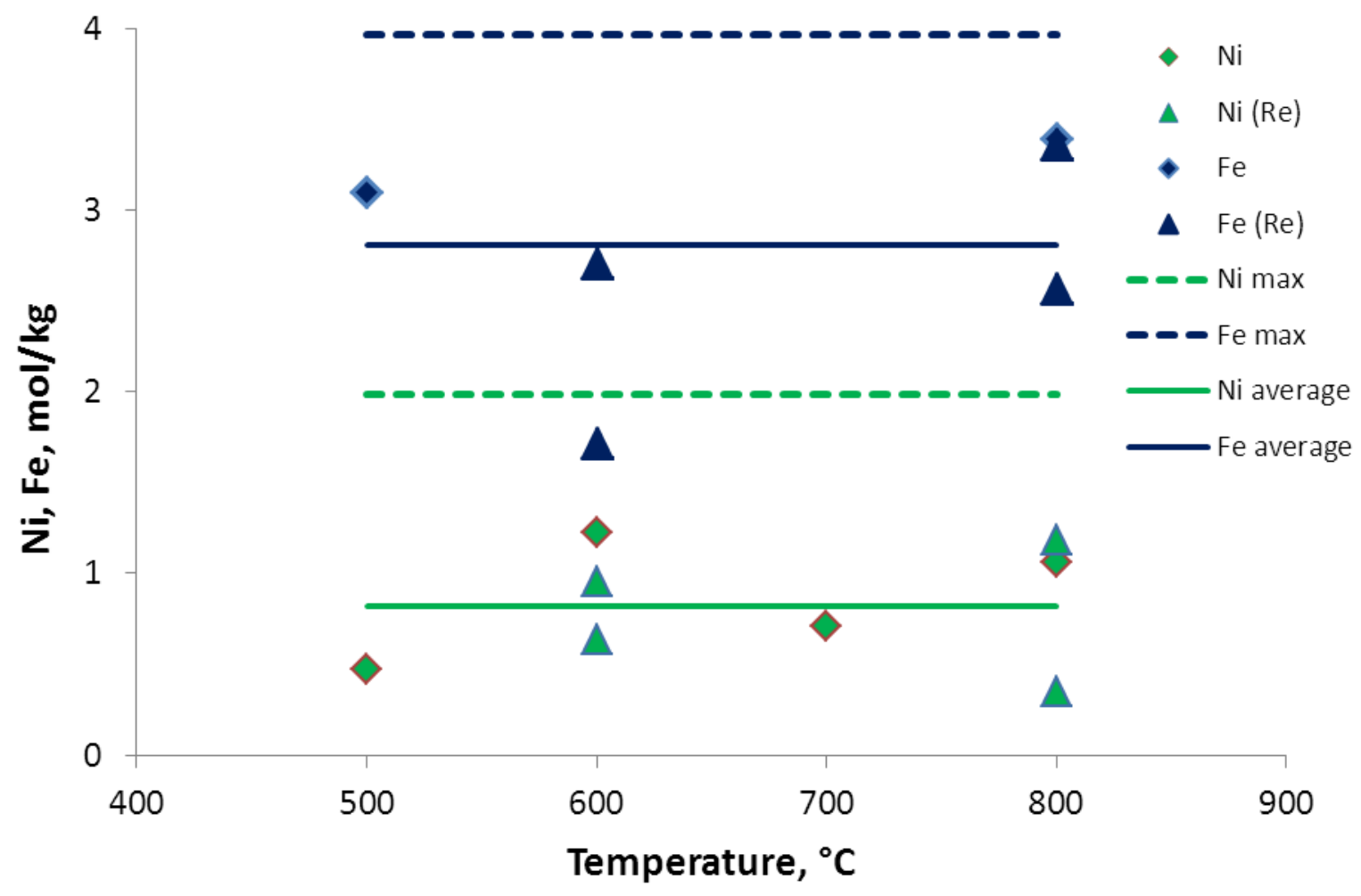

Figure 2. Spinel Yield vs. Temperature

Table 6. $\mathrm{KReO}_{4}$ Content in CT4, XRD Data

\begin{tabular}{c|cc}
\hline $\mathbf{T ,}{ }^{\circ} \mathbf{C}$ & $\begin{array}{c}\text { Mass } \\
\text { fraction }\end{array}$ & $\begin{array}{c}\text { Fraction } \\
\text { retained }\end{array}$ \\
\hline $\mathbf{6 0 0}$ & 0.2578 & 0.708 \\
$\mathbf{8 0 0}$ & 0.2107 & 0.578 \\
$\mathbf{6 0 0}$ & 0.1476 & 0.663 \\
$\mathbf{8 0 0}$ & 0.1065 & 0.478 \\
\hline
\end{tabular}

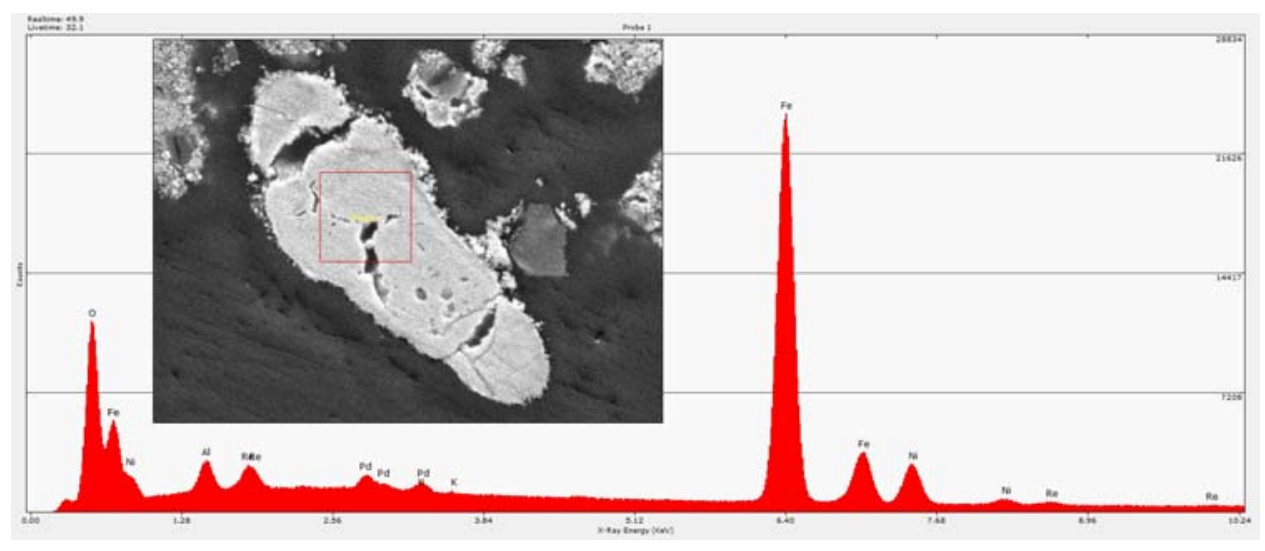

Figure 3. SEM-EDS of CT4A600R $(\mathrm{Re} / \mathrm{Ni}=1)$ 
Table 7. SEM-EDS Data (atomic fraction)

\begin{tabular}{l|lll} 
Average & Fe & Ni & Re \\
\hline $\mathbf{6 0 0}$ & 0.329 & 0.100 & 0.0079 \\
$\mathbf{8 0 0}$ & 0.256 & 0.085 & 0.0059 \\
total & 0.297 & 0.093 & 0.0070
\end{tabular}

Standard deviation

\begin{tabular}{l|rrr}
\hline $\mathbf{6 0 0}$ & 0.148 & 0.036 & 0.0032 \\
$\mathbf{8 0 0}$ & 0.127 & 0.010 & 0.0004 \\
total & 0.132 & 0.028 & 0.0030 \\
\multicolumn{4}{l}{ Spinel cation fraction } \\
\hline $\mathbf{6 0 0}$ & 0.754 & 0.228 & 0.018 \\
$\mathbf{8 0 0}$ & 0.738 & 0.245 & 0.017 \\
total & 0.748 & 0.235 & 0.018 \\
\hline
\end{tabular}





\subsection{Discussion}

This study is part of a larger project to immobilize Tc in HLW glass. While we are in the initial stages of this study, there is a high probability that Re will be found in satisfactory concentration in spinel. If so, we can expect that satisfactory amounts of Re will be carried by spinel into HLW glass. 



\subsection{Conclusions}

Trevorite and other spinels can be produced from a nitrate mixture at temperatures as low as $500^{\circ} \mathrm{C}$. Spinel crystals can contain several percent of Re. For future work, the Re-containing spinel will be added to HLW feed to determine the fraction of Re retained in glass. 



\subsection{References}

1. K. Righter, J. T. Chesley, D. Geist, J. Ruiz, "Behavior of Re during Magma Fractionation: an Example from Volcán Alcedo, Galápagos,” J. Petrology, 39, 785-795 (1998).

2. P. Izak, P. Hrma, B.W. Arey, T.J. Plaisted, "Effect of feed melting, temperature history, and minor component addition on spinel crystallization in high-level waste glass,” J. Non-Crystalline Solids, 289, 17-29 (2001).

3. B. Senthilkumar, R.K. Selvan, P. Vinothbabu, I. Perelshtein, A. Gedanken, "Structural, magnetic, electrical and electrochemical properties of $\mathrm{NiFe}_{2} \mathrm{O}_{4}$," J. Mater. Chem. Phys., (Article in press).

4. E.M.Levin, C.R. Robbins, H.F. McMurdie, "Phase diagrams for ceramists, Vol. I,” p. 335, The American Ceramic Society (1964).

5. M. Mika, P. Hrma, M. Schweiger, "Rheology of Spinel Sludge in Molten Glass,” CeramicsSilikaty 44, 86-90 (2000). 



\section{Distribution}

No. of

Copies

1 David Kosson

Cornelius Vanderbilt Professor of Engineering,

267-A Jacobs Hall, Vanderbilt University

VU Station B 351831

Nashville, TN 37232

1 Delmar Noyes

Deputy Federal Project Director

DOE

2440 Stevens Center,

Mailstop: H6-60

Richland, WA 99354

1 AA Kruger

DOE

3000 George Washington Way

Mailstop: C-107

Richland, WA 99354
No. of

\section{Copies}

6 Local Distribution

Pacific Northwest National Laboratory

DE Knudson H6-60

PR Hrma K6-24

JS McCloy K6-24

D-S Kim

K6-24

A Goel

K6-24

MJ Schweiger 




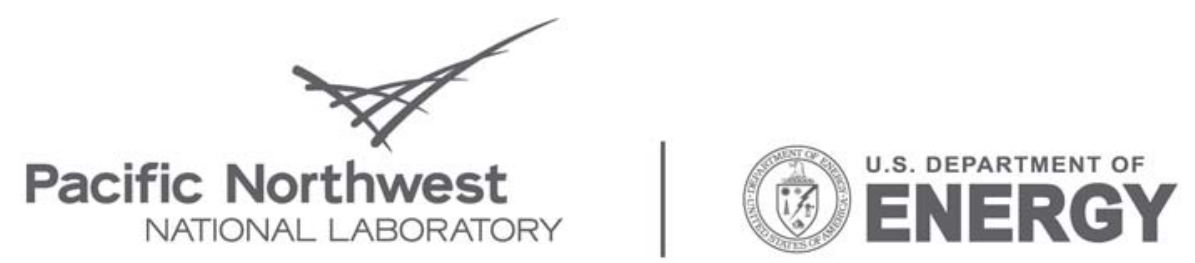

Proudly Operated by Battelle Since 1965

902 Battelle Boulevard

P.O. Box 999

Richland, WA 99352

1-888-375-PNNL (7665)

www.pnl.gov 